\title{
SiC 半導体パワーデバイスの電力変換回路利用における課題
}

\author{
舟木 剛*

\section{Challenges in Utilization of SiC Power Devices for Power Conversion Circuit}

Tsuyoshi FUNAKI*

* 大阪大学（† 565-0871 大阪府吹田市山田丘 2-1）

* Osaka University (2-1 Yamada-oka, Suita, Osaka 565-0871)

\section{1. はじめに}

パワーエレクトロニクスは, エネルギ利用を高効率化す る技術として知られている。すなわち, 半導体パワーデバ イスのスイッチング動作を用いた電力変換により電圧・電 流・周波数などの状態量を任意の值に変換・制御すること で, 従来の電気機器を効率の良い動作点で利用することを 可能とするだけでなく, 従来電気が用いられてこなかった アプリケーションを電気化することにより制御性・機能性 を向上させ，エネルギ消費の削減を実現する技術であ る 1) 3)。さて, パワーエレクトロニクス化によるエネルギ 損失削減効果は大きいが, さらなる省エネルギ化のために は電力変換部での損失削減・小型軽量化が必要となる。パ ワーエレクトロニクスアプリケーションでのシステム全体 を含む電力変換損失低減の流れとして, 回路の高電圧・小 電流化による導通損失の低減があり, 電力変換回路に用い る半導体パワーデバイスに対して高耐圧化が求められてい る。また電力変換回路の構成に占めるコンデンサ・リアク トル・トランスなどの受動素子やヒートシンクなどの放熱 機構における面積・体積・重量の割合は大きく, これらの 小型軽量化が求められている。受動素子の小型化にはス イッチング動作の高周波数化が効果的であるが, スイッチ ング損失はスイッチング周波数に比例し, スイッチング速 度に反比例することから, 半導体パワーデバイスにおける スイッチング動作の高速化が不可欠である。また半導体パ ワーデバイスにおける導通損失やスイッチング損失を 0 に することはできないため, 半導体パワーデバイスを冷却す るための放熱機構をなくすことはできず，高温動作による 放熱機構の小型化・簡素化が期待されている。

このような要求に対し, 従来 $\mathrm{Si}$ 半導体を用いたパワーデ バイスでは, さまざまな素子構造や製造プロセスの開発に より解決を図ってきた ${ }^{4)}$ 。しかしながら半導体材料の物性 值限界を超えることはできないため, その限界が高い $\mathrm{SiC}$ や GaN などのワイドバンドギャップ半導体がパワーデバイ スに適用されつつある。ただし, 半導体材料を変えるだけ
でこれらの課題がすべて解決れるわけではなく, 解決しな ければならない課題が新たに生じる。本稿では特に高速ス イッチング動作に関する課題について述べる。

\section{2. ワイドバンドギャップ半導体パワーデバイスの高速 スイッチング}

半導体パワーデバイスでは, オン抵抗を小さくすること により導通損失を低減することが求められる。高耐圧の半 導体パワーデバイスのオン抵抗では, 困 1 に示す不純物濃 度を低くする $\left(\mathrm{n}^{-}\right)$ことで耐圧を維持するドリフト層の抵抗 が支配的となる。ドリフト層のみで電圧を維持すると仮定 すると, 半導体の絶縁破壊電界 $E_{c}$, ドリフト層の不純物濃 度 $N_{d}$ と耐圧 $V_{b d}$ との関係は次式となる。

$$
V_{b d}=\frac{\varepsilon_{s}}{2 e N_{d}} E_{c}^{2}
$$

ただし， $\varepsilon_{s}$ は半導体の誘電率， $e$ は単位電荷である。

これより耐圧 $V_{b d}$ とオン抵抗 $R_{d}$ の関係を求めると次式と なる。

$$
R_{d}=\frac{4 V_{b d}{ }^{2}}{\mu \varepsilon_{s} A E_{c}^{3}}
$$

ただし， $\mu$ はキャリアの移動度， $A$ は導通領域の断面積 である。

すなわちオン抵抗は耐圧 $V_{b d}$ の 2 乗に比例するため, 耐 圧を高くすると急激にオン抵抗は高くなる。一方オン抵抗 は半導体の絶縁破壊電界 $E_{c}$ の 3 乗に反比例するが, ワイド バンドギャップ半導体である $\mathrm{SiC}$ は, $\mathrm{Si}$ 半導体に比べ絶縁 破壊電界が 1 桁ほど大きい。このため $\mathrm{SiC}$ 半導体を用いる ことで, 高耐圧パワーデバイスのオン抵抗を大幅に下げる ことができる。ただしここで考えているオン抵抗は，ドリ フト層にドープされた不純物による多数キャリアでの導通 動作を考えている。 $\mathrm{Si}$ 半導体を用いたバイポーラタイプの 高耐圧パワーデバイスでは，ドリフト層の不純物濃度を高 くすることができないが, 半導体の PN 接合を介して異な る半導体 $\left(\mathrm{p}^{+}\right)$より小数キャリア（正孔）をドリフト層 $\left(\mathrm{n}^{-}\right)$ に注入することによりオン抵抗を下げる伝導度変調効果を 

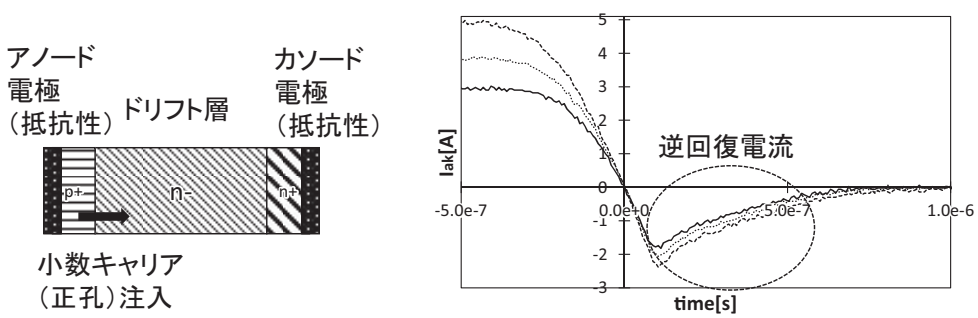

(a) Si PiNダイオード
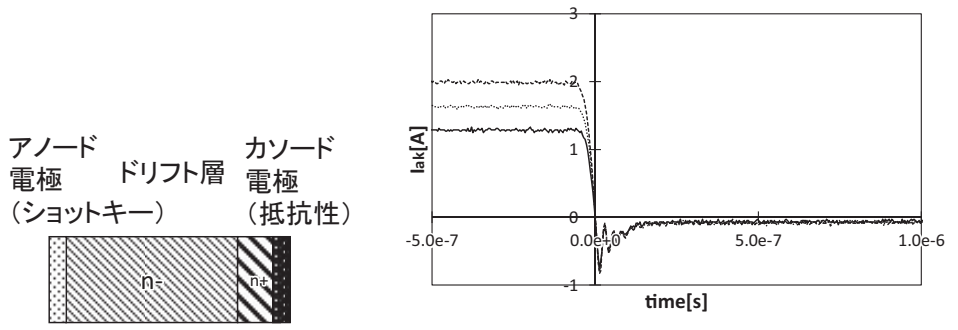

(b) SiC ショットキーバリアダイオード

図 1. ダイオードの構造とターンオフにおける電流応答

利用している。PN 接合電位が重畳されるものの, 実用上十 分に低いオン抵抗を得ることができる。

さて, 電力変換回路における半導体パワーデバイス利用 では, 導通・遮断の定常状態以外に，スイッチングの過渡 動作を考える必要がある。バイポーラタイプのデバイスの 遮断状態から導通状態への遷移において，小数キャリアを 注入して伝導度変調効果が表れるまでの順回復, 導通状態 から遮断状態への遷移において, 小数キャリアが消滅し空 乏層が広がる逆回復やテール電流の有無がスイッチング動 作に影響する。ここでは特に図 1 (a) に示すターンオフ動作 における逆回復現象とテール電流について述べる。

図 1 に Si PiN ダイオード (PiND) と SiC ショットキーバ リアダイオード (SBD) のターンオフ動作における電流の時 間応答を示す。PiND ではターンオフ開始とともにドリフト 層への小数キャリアの注入がとまり, 再結合もしくは掃き だしにより小数キャリアがドリフト層から消滅する過程に おいて, 電流が順方向から 0 を下回り逆方向電流として流 れる。導通状態において注入される小数キャリアの量は順 方向電流にほぼ比例することから, 図 1 (a)に示すように順 方向電流が大きくなるに従い, 逆方向に流れる電流も大き くなる。また電流変化率 $\mathrm{di} / \mathrm{dt}$ の大きい高速なスイッチン グ動作に対しては，導通状態変化の遷移時間が短くなるた め，遷移期間中に再結合する小数キャリアも少なくなる。 したがって掃き出さなければならない小数キャリアの量が 相対的に大きくなり, これが大きな逆方向電流として現れ る。このダイオードに過渡的に流れる逆方向電流が, ダイ オードのスイッチング動作を引き起こしているトランジス 夕の順方向電流として流れることから, ダイオードとトラ ンジスタ両方でのスイッチング損失となる。また逆方向電 流が最大となった時点から，ドリフト層では空乏層が拡大 し遮断状態に遷移するが, 不純物濃度が低いことから印加

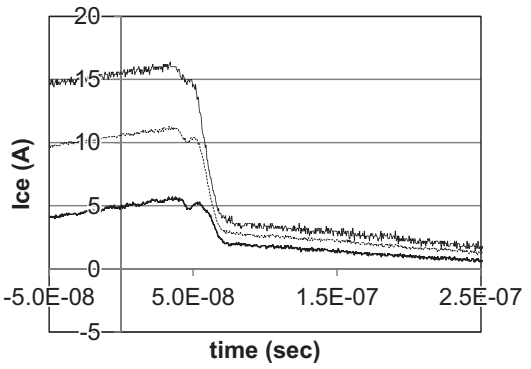

(a) Si IGBT

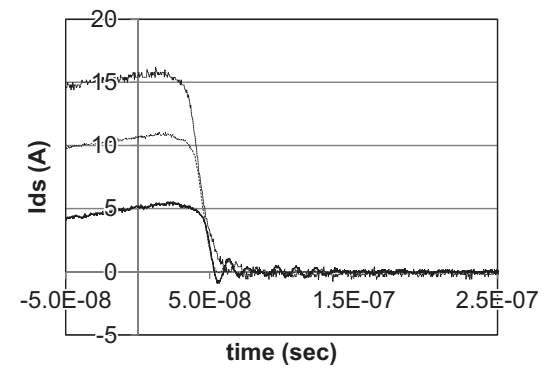

(b) SiC MOSFET

図 2. トランジスタのターンオフにおける電流応答

されている高電圧に対して掃き出す多数キャリアの量は少 なく，大きな $\mathrm{di} / \mathrm{dt}$ で電流が 0 に戻る。この時回路配線の 寄生インダクタンスにより生じた起電力がサージ電圧とし て回路素子に重畳されるとともに，電磁ノイズの原因とな る。多数キャリアのみで動作する SBD では, 図 1 (b) に示 すように小数キャリアに伴う逆回復現象は生じない。ただ し，ドリフト層の空乏化における多数キャリアの掃き出し に伴う逆方向電流が流れる。

図 2 に Si IGBT と SiC MOSFET のターンオフ動作におけ る電流の時間応答を示す。図 2 (b) に示す MOSFET では, ゲートーソース間電圧が閾值電圧を下回るとゲート下の チャネルが消失し，同時にドレイン電流が遮断される。一 
方図 2 (a) に示す IGBT はバイポーラトランジスタのベース をMOSFETで駆動するのと等価な動作となっており, MOSFET 単体の動作とは異なる。すなわち $\mathrm{n}$ チネル IGBT では, nチャネル MOSFET が PNP トランジスタのベースを 駆動することで導通状態を制御しており，MOSFET はトラ ンジスタへベース電流として小数キャリアを注入すること はできるが, 注入した小数キャリアを引き抜くことはでき ないため, MOSFET 部が遮断した後にPNPトランジスタは ベースに注入された小数キャリアが消滅することで遮断状 態に回復する。図 2 (a) においてコレクタ電流が急激に電流 が低下する部分が, MOSFET 部のチャネル電流の遮断に相 当し, その後ゆっくりと減少していく電流が PNP トランジ スタのベース部に注入された小数キャリアにより流れる テール電流である。

以上のように, PiND や IGBT などのバイポーラデバイス は, 小数キャリアによる伝導度変調により導通抵抗を下げ ることができる。しかしながら, デバイスを導通状態から 遮断状態に遷移させるためには, 蓄積された小数キャリア を再結合または掃き出すことで消滅させることが必要であ り, これに時間を要するとともにスイッチング損失の原因 となっている。高耐圧のパワーデバイスに $\mathrm{SiC}$ 半導体を適 用することで, 小数キャリアによる伝導度変調を用いずに 低抵抗化することができることから, ユニポーラデバイス 構造を採用することができ, 高速なスイッチング動作が可 能となる。高速スイッチング動作によりスイッチング損失 が低減され, 高周波数での動作も可能となる。一方で高速 スイッチング動作に伴い生じる問題もある。次章では, 特 に高速なスイッチング動作に伴いトランジスタの駆動回路 において生じる課題について述べる。

\section{3. 高速スイッチング動作に伴うゲート電圧変動}

図 3 に電力変換回路で用いられるハーフブリッジとゲー 卜駆動回路を示す。ハーフブリッジは上下アームで構成さ れ, 二並列接続することで太陽光発電のパワーコンディ ショナーなどで用いられる単相フルブリッジ回路, 三並列 接続することでモータ駆動などに用いられる三相フルブ リッジ回路が構成できる。情報通信機器で用いられる低圧 デバイスの CMOS 構成とは異なり, 電力変換回路は通常 $\mathrm{N}$ チャネルパワーデバイスのみで上下アームを構成する。こ のため上下アームの MOSFET には, 図 3 (a) に示すように 電位が切り離された個別のゲート駆動用の電源が必要とな る。図 3 (b) に示す下側アームの導通時に上側アームのゲー 卜駆動用電源として用いるコンデンサを充電するブートス トラップ方式もあるが, 高周波スイッチング動作では十分 なコンデンサの充電時間を確保することが難しい。また $\mathrm{Si}$ IGBT と同様に耐圧 $1,000 \mathrm{~V}$ を超える SiC MOSFET でもゲー 卜閾值電圧は 3〜 $5 \mathrm{~V}$ 程度と低い。このため高速なスイッチ ング動作に伴ってゲート電圧が変動した際に, これが闇值

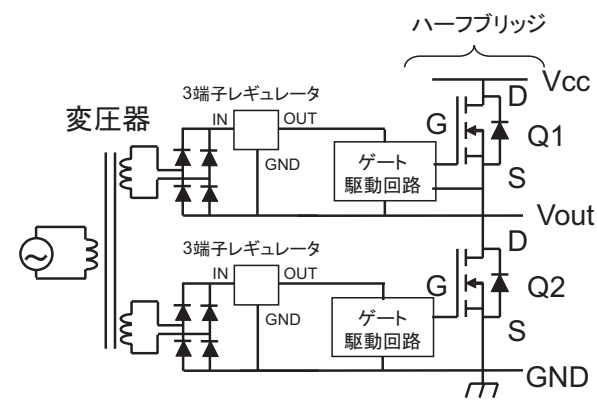

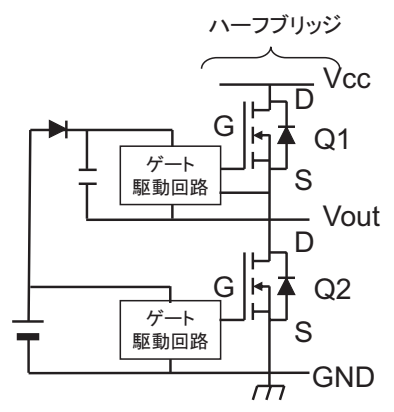

(b) ブートストラップ方式

図 3. ハーフブリッジとゲート駆動回路

電圧を超えることで，遮断状態にあるべき素子が導通する セルフターンオン現象が生じることがある ${ }^{5) \sim 7) 。 以 下 て ゙ は ~}$ その発生メカニズムについて述べる。

上下アームともに閾值電圧より低いゲート電圧が, ゲー 卜駆動回路より印加されてチャネルが遮断状態にある場合 を考える。ただし下側アームは, MOSFET のボディダイ オードを介して導通しており, そのドレイン電圧は GND レ ベルにある。また上側アームのドレインーソース間には電 源電圧が印加されている。ここで上側アームを高速にター ンオンさせると, 図 5 (a)に示すように遮断状態にある上側 アームのドレインーソース間に印加された電源電圧が，大 きな $\mathrm{dv} / \mathrm{dt}$ で低下すると同時に, 下側アームのドレインー ソース間に大きな $\mathrm{dv} / \mathrm{dt}$ で電圧が印加される。MOSFET の ゲート端子は, ドレインおよびソース端子とは絶縁されて いるが, 図 4 (a) に示すようにゲート酸化膜や半導体の空乏 層を介した寄生容量 Cgs, Cgd が存在している。ゲート端子 は, ゲート抵抗 Rg を介してゲート駆動用電源につながつ ているため，その等価回路は図 4 (b) のようになる。ゲート 端子が開放もしくは高いゲート抵抗を介してゲート駆動回 路に接続されている場合, ドレインーソース間に印加され た電圧が Cgs, Cgd によって容量分割され, ゲートーソース 間の電圧として現れる。ただし高速なスイッチング動作を 考えているここでは，比較的小さなゲート抵抗を介して ゲート駆動電源に接続されるため, ゲート電圧は容量分割 されたドレイン電圧とはならない。下側アームのドレイ ンーソース間に, 立ち上がり速度 $k_{v}=\frac{d v}{d t}$ で電圧が印加され 


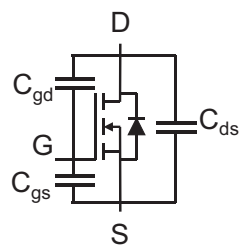

(a) MOSFET 等価回路

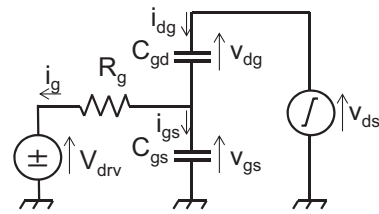

（b）ゲート駆動回路を含んだ等価回路

\section{図 4. MOSFET とゲート駆動回路の等価回路}

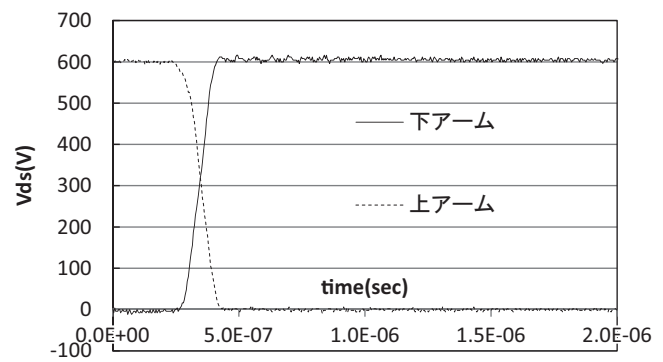

(a) 上下アームドレインーソース間電圧

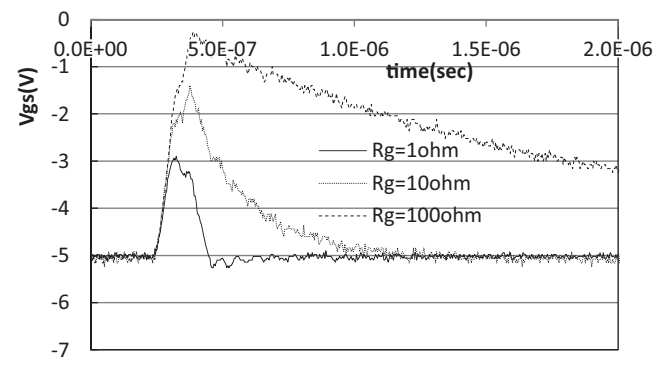

(b) ゲート電圧

図 5. ドレイン電圧印加に対するゲート電圧変化

る場合，ゲートーソース間に誘起する電圧 $v_{g s}$ は次式のよう な時間応答になる ${ }^{8)}$ 。ただしここでは端子間容量 $\mathrm{Cgd}, \mathrm{Cgd}$ の電圧依存性は無視している。

$$
v_{g s}=R_{g} C_{g d} k_{v}\left[1-e^{-\frac{t}{R_{g}\left(C_{g s}+C_{g d}\right)}}\right]+V_{d r v}
$$

すなわち，ドレインーソース間に印加された電圧 $v_{d s}$ によ りゲート電圧 $v_{g s}$ が変化するが, その大きさは印加されるド レイン電圧の変化速度 $k_{v}$ およびゲート抵抗 $R_{g}$, ゲートード レイン間容量 $C_{g d}$ に比例する。高速スイッチング動作では 電圧変化速度 $k_{v}$ が大きくなるため, ゲート電圧 $v_{g s}$ も高く なる。ゲート抵抗はスイッチング速度を調整するために用 いられるが，オフの定常状態においてもドレイン電圧印加 により生じるゲート電圧変化を抑制するためにできるだけ

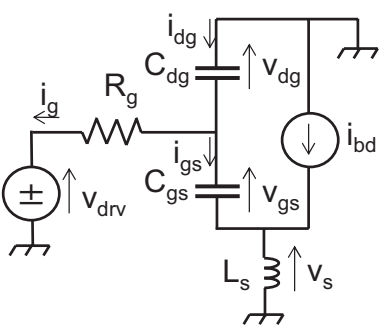

（a）ゲート駆動回路を含んだ等価回路

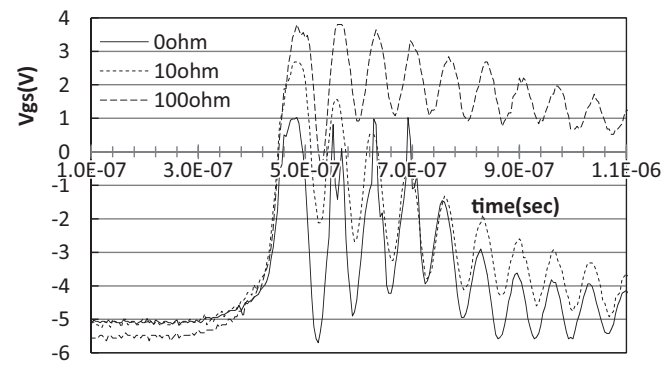

(b) ゲート電圧

図 6. ダイオードのターンオフに対するゲート電圧変化

小さい值とすることが望ましい事がわかる。

上述のドレイン電圧印加によるゲート電圧変動では, MOSFET の寄生成分である端子間容量による影響を考慮し た。電力変換回路では，パワーデバイスの持つ寄生容量以 外にプリント配線板やブスバー配線などに寄生インダク夕 ンスが存在する。ここでは特にソース端子の配線により生 じる寄生インダクタンスがゲート電圧変動に与える影響に ついて考える。

ハーフブリッジの中間端子が，モータやリアクトルなど の誘導負荷に接続されており，上下アームのゲート端子に MOSFET をオフとする閾值電圧より低いゲート電圧が駆動 回路より印加されている状態では, 負荷電流の方向により 上下アームいずれかの還流ダイオードが導通する。ここで は下側アームのダイオードが導通している状態を考える。 図 6 (a) に等価回路を示すように，上側アームがターンオン すると，下側アームのダイオードに流れていた電流が上側 アームの MOSFET に転流する。上側アームの MOSFET の ターンオンに打ける電流変化率を $k_{c}=\frac{d i}{d t}$ とすると, 下側 アームのダイオードに流れている順方向電流は $-k_{c}$ の電流 変化率で減少する。この時下側アームのソース端子の寄生 インダクタンス $L_{s}$ に誘導される電圧によりソース端子の電 位が持ち上げられ，GND 電位に対して高くなる。ソース端 子とゲート端子の寄生相互インダクタンスを無視すると, GND 電位に対するゲート端子の電位はこの時変化しない。 したがって, ソース端子の寄生インダクタンスにおいて生 じた起電力により図 6 (b) に示すように, ゲートーソース間 電圧は上昇する。一方で，ダイオードが逆電流ピーク值と なるまでは遮断状態とならず，下側アームに流れる電流が 
変化してもドレインーソース端子間の電圧は変化しないこ とから, 先に述べた静電結合によるゲート電圧変化は生じ ない。この下側アームのダイオード電流の減少過程におけ るゲート電圧の応答は次式となる ${ }^{9)}$ 。

$$
\begin{aligned}
v_{g s}(t)= & \frac{k_{c} L_{s}}{2}\left\{\left(1+\frac{A}{\sqrt{B}}\right) e^{\frac{A-\sqrt{B}}{2 C_{g s} L_{s}} t}+\left(1-\frac{A}{\sqrt{B}}\right) e^{\frac{A+\sqrt{B}}{2 C_{g s} L_{s}} t}\right\} \\
& -k_{c} L_{s}+\text { const }
\end{aligned}
$$

ただし $, A=R_{g}\left(C_{d g}+C_{g s}\right), \quad B=A^{2}-4 C_{g s} L_{s}$ 。

すなわちゲートーソース間に生じる電圧 $v_{g s}$ は, 電流変化 率 $k_{c}$ に比例するとともにソースインダクタンス $L_{s}$ にも比 例する。前述の静電結合によるゲート電圧変動では, ゲー 卜抵抗 $R_{g}$ の影響が大きいことを示したが, ソース部の寄生 インダクタンス $L_{s}$ における誘導電圧によるゲート電圧変化 では，ゲート抵抗の影響が小さくなることが分かる。

先に述べたように，高速なスイッチング動作におけるダ イオード電流は, ターンオフ過程において一旦逆方向に流 れてから 0 まで戻る逆回復現象を示すことが知られてい る。ダイオード電流が負のピーク值となった後に 0 に戻る 過程では di/dtの符号は逆となる。このためソース部の寄 生インダクタンスにおいて生じる電圧により, ソース端子 の電位は GND 電位より低くなる。この電圧はゲートソー ス間に負のバイアス電圧として重畳されることから, MOSFET におけるチャネルの遮断状態に影響を与えない。 ただし，上下アームのドレイン端子などに存在する寄生イ ンダクタンスにおいても同様に起電力が生じ, 電源電圧と 同極性の電圧が上下アームのドレインーソース間に重畳さ れる。このため前述のドレイン電圧の印加による MOSFET の端子間容量を介したゲート電圧変化に対して影響を与え ることが考えられるため, 寄生インダクタンスが大きい場 合には考慮が必要となる。

\section{4. おわりに}

従来のパワーエレクトロニクスでは, $\mathrm{Si}$ 半導体パワーデ バイスの適用を前提に電力変換回路を開発しており, $\mathrm{Si}$ パ ワーデバイスを $\mathrm{SiC}$ パワーデバイスに置き換えただけでは, $\mathrm{SiC}$ パワーデバイスの持つ性能を十分に引き出すことがで きない。本稿では, 電力変換回路における $\mathrm{SiC}$ パワーデバ イスの利用において, その特徴を活かした高速スイッチン グ動作において生じる課題について述べた。本稿で取り上
げた課題以外にも, 小型軽量化に対応するための受動素子 などの周辺部材の開発, 高温動作に対応する実装材料の開 発や信頼性向上など, 新たな開発を必要とする課題が山積 している。これらの課題を個々に解決してもその効果は限 定的であるが，それらを組み合わせたシステムとして解決 することで，より大きな効果が期待できる。

(2014.5.30- 受理)

\section{文献}

1) N. Mohan, T. M. Undeland, and W. P. Robbins: "Power Electronics: Converters, Applications, and Design," Wiley, 1995

2) J. G. Kassakian, M. F. Schlecht, and G. C. Verghese: "Principles of Power Electronics," Prentice Hall, 1991

3) M. Rashid: "POWER ELECTRONICS HANDBOOK," Butterworth-Heinemann, 2010

4) 戸倉 : “四半世紀にわたる IGBT 開発の軌跡（1984 年～2009 年), ”電学論 D, Vol. 131, No. 1, pp. 1-8, 2011

5) K. Murata and K. Harada: “Analysis of a self turn-on phenomenon on the synchronous rectifier in a DC-DC converter," Proc. INTELEC 2003, pp. 199-204, 2004

6) K. Murata and K. Harada: "A self turn-on mechanism of the synchronous rectifier in a DC-DC converter," Proc. INTELEC 2004, pp. 642-646, 2004

7) Y. Kawaguchi, S. Ono, K. Kinoshita, and A. Nakagawa: "Study of Low side MOSFET Self Turn-on Phenomenon in Synchronous Bulk Converter by Spice Simulator,” IPEC, pp. 965-970, 2005

8) T. Funaki: "Comparative study of self turn-on phenomenon in high-voltage $\mathrm{Si}$ and $\mathrm{SiC}$ power MOSFETs," IEICE ELEX, Vol. 10, No. 21, p. 20130744, 2013

9) T. Funaki: "A study on the self turn-on phenomenon of power MOSFET induced by the turn-off operation of body diodes," IEICE ELEX, Vol. 11, No. 13, p. 20140350, 2014

舟木 剛（ふなき つよし）

著者紹介

1991 年 3 月大阪大学工学部電気工学科卒業。

1993 年 3 月同大学大学院工学研究科電気工学専攻博士前期課程修了。 1994 年 4 月大阪大学助手。

2001 年 4 月同大学講師。

2002 年 8 月京都大学助教授。

2008 年 4 月大阪大学教授となり現在に至る。

博士 (工学) 